Supplement of

\title{
Real-time measurements of secondary organic aerosol formation and aging from ambient air in an oxidation flow reactor in the Los Angeles area
}

Amber M. Ortega et al.

Correspondence to: Jose L. Jimenez (jose.jimenez@ colorado.edu)

The copyright of individual parts of the supplement might differ from the CC-BY 3.0 licence. 


\section{Quantification of AMS Reactor Data}

3 All aspects of quantification of AMS data are the same as described by Hayes et al. (2013). Here

4 we describe only those aspects where additional analysis or corrections are needed specifically for

5 the reactor output data.

\subsection{AMS Collection Efficiency}

7 Quantification of AMS concentration data requires a correction for particle bounce at the

8 vaporizer, referred to as the collection efficiency (CE; Canagaratna et al., 2007). The composition-

9 dependent CE formulation of Middlebrook et al. (2012) was used by Hayes et al. (2013) to estimate

$10 \mathrm{CE}$ for the ambient data, leading to good intercomparisons with multiple collocated instruments as

11 documented by that study. The same methodology has also been applied to reactor output

12 measurements.

13 Although the focus of this paper is OA formation and aging, a brief summary of the observed

14 evolution of the inorganic species: (a) Sulfate formation proceeds as expected from the $\mathrm{OH}+\mathrm{SO}_{2}$

15 reaction. A quantitative analysis of sulfate formation is shown in Palm et al. (2016), which reports

16 results from a similar experiment from our group, but in a forest environment. That analysis

17 provides evidence that the corrections for losses of low volatility species developed in that work

18 are appropriate. (b) Nitrate formation is more complex since $\mathrm{OH}+\mathrm{NO}_{2}$ is a fast reaction, but

$19 \mathrm{HNO}_{3}$ is semivolatile and the formation of $\mathrm{NH}_{4} \mathrm{NO}_{3}$ also depends on the availability of $\mathrm{NH}_{3}(\mathrm{~g})$.

20 (c) The aerosols in the output of the flow reactor during CalNex are neutralized, similarly to the

21 ambient aerosols (Hayes et al., 2013). 
23 Fig. S2a shows the time series of reactor and ambient aerosol concentrations and estimated CE.

24 Ambient CE periodically rises above 0.5 due to larger fractions of ammonium nitrate aerosol, 25 which leads to reduced particle bounce (Middlebrook et al., 2012). The reactor typically formed 26 additional ammonium sulfate and ammonium nitrate beyond ambient concentrations at the same 27 time as ambient levels peak for those compounds, thus the reactor CE profile has a very similar 28 temporal structure to ambient. However, Fig. S2b shows that the estimated CE increases at the 29 highest reactor $\mathrm{OH}_{\text {exp }}$, due to additional ammonium nitrate formation in the reactor with increased 30 photochemical age.

31 Highly acidic particles, as indicated by the ammonium balance, can also lead to increased CE in 32 the AMS (Middlebrook et al., 2012). The ammonium balance method compares the measured 33 ammonium to that required to fully neutralize observed sulfate, nitrate, and chloride (Zhang et al., 34 2007), as shown in Fig. S3. Ambient and reactor results have near identical slopes that are 35 indistinguishable from the one-to-one line within the uncertainties of the measurements, signifying 36 full neutralization for both. Furthermore, this comparison indicates that the reactor is producing 37 similar inorganic composition to that observed in the atmosphere as nitric acid and sulfuric acid 38 gases are formed in the reactor and fully neutralized by ammonium forming ammonium nitrate 39 and ammonium sulfate. Thus no correction of CE due to the presence of highly acidic particles are 40 needed in this study.

41 Comparison of AMS and SMPS measurements for ambient and reactor data, shows that ambient 42 data falls along a one-to-one line, indicating both instruments are measuring the same amount of 43 mass within the uncertainties ( Fig. S4a). Reactor output data has a slightly higher slope of 1.14, 44 i.e. the AMS measures $\sim 14 \%$ higher mass than the SMPS from the reactor and also shows a cluster 45 of points where SMPS>AMS due to periods where substantial mass is formed at small particle 
46 sizes (see below). Both slopes are within the combined uncertainties of the two measurements.

47 Fig. S4b shows the relative increase in aerosol concentration in the reactor (i.e. ratio of reactor to 48 ambient concentrations) for the SMPS vs. AMS which also compare well, on average (slope = 49 1.05), but with considerable scatter, most of which is likely due to additional measurement noise 50 introduced from ratioing multiple short measurements. Evaporation of freshly formed $\mathrm{NH}_{4} \mathrm{NO}_{3}$ in

51 the longer residence times in the SMPS (compared to the faster AMS analysis) where the sheath 52 flow may have reduced $\mathrm{NH}_{3}$ and $\mathrm{HNO}_{3}$ gas concentrations, has been observed with this 53 experimental setup, and may be a cause of the slightly larger slope for reactor output conditions. 54 A small underestimation of AMS CE for the reactor conditions could also result in this observation.

55 It is also possible that the AMS relative ionization efficiency (RIE) of organic species is lower for 56 more oxidized species (Jimenez et al., 2003; D. Murphy, pers. Comm. 2015), although no clear 57 evidence has been reported for ambient data (e.g. Docherty et al., 2011). If that effect played a 58 dominant role here, we would expect the reactor slopes to be lower, rather than slightly higher than 59 1. Thus we conclude that any RIE changes are small and cannot be separated from other effects 60 such as small changes in CE, nitrate evaporation in the SMPS, or differences in particle 61 transmission (next section).

\subsection{Accounting for Particle Mass below the AMS Lens Transmission}

As the reactor exposed ambient air to high levels of $\mathrm{OH}$ and $\mathrm{O}_{3}$, new particle formation and growth was sometimes observed. To fully account for the mass of all particles formed in the reactor, it is necessary to quantify the mass of small particles below the AMS lens transmission size (Zhang et al., 2004). SMPS data was used to estimate the total mass concentration below the AMS size cut. First, particle transmission from plumbing line losses was corrected using the Particle Loss 
Calculator (von der Weiden et al., 2009) for this experimental plumbing and flowrate configuration

69 for both reactor and ambient SMPS data, with transmission curves as shown in Fig. S5. Second,

70 the measured SMPS mass that is below the AMS transmission curve was estimated using a

71 published AMS lens transmission parameterization (Knote et al., 2011) multiplying the SMPS

72 size-dependent mass by the size-dependent AMS lens fractional loss (1-transmission). Figure S6a

73 shows a time series of estimated reactor and ambient mass missed by the AMS due to transmission

74 losses. Since corrections needed to account for the contribution of these small sizes to total mass

75 is small for ambient data (on average 1.7\%), Hayes et al. (2013) did not apply a correction to AMS

76 ambient data. Fig. S6b shows the estimated fraction of the reactor output mass that is below the

77 AMS lens transmission size vs. total photochemical age in days (at $\mathrm{OH}=1.5 \times 10^{6} \mathrm{molec} . \mathrm{cm}^{-3}$ ).

78 An average of $6.2 \%$ of the total reactor output mass is estimated to be below the AMS lens

79 transmission, with no dependence on photochemical age except possibly at the highest values $(>20$

80 days of age).

81 We note that the AMS measurements from the reactor may be biased $\sim 6 \%$ low, on average, and

82 sometimes as much as $20 \%$. This non-measured mass likely has a large OA fraction (see Fig. S8).

83 Thus, reactor-reported mass enhancement above ambient may be underestimated by these

84 amounts. Given the 6.2\% AMS underestimation from particle transmission of small sizes in the

85 reactor, and the apparent $14 \%$ overestimation in the AMS vs SMPS comparison, but overall good

86 agreement in the relative enhancement of total aerosol between both instruments, we have not

87 corrected for these differences as the net correction would be small and within the uncertainties of

88 the measurement, while the correction process would introduce additional noise. 


\section{Supplementary Captions}

92 Figure S1: Results of computerized fluid dynamics (CFD) simulations comparing two OFR 93 configurations. (a) Tube inlet, similar to Lambe et al. (2011); (b) Large open face inlet (11.9 cm 94 diameter) as used in this field study. Colors are contours of positive horizontal velocity. White regions involve horizontal velocities, i.e. recirculation regions. The extensive recirculation regions of case (a) are almost completely removed in case (b), resulting in a narrower residence time distribution. Simulations were conducted using the FLUENT software, using cylindrical symmetry, with air at 1 atm and $293 \mathrm{~K}$.

Figure S2: (a) Estimated AMS collection efficiency (CE) and corresponding AMS mass concentration time series for ambient and reactor data (after applying CE correction). Estimated $\mathrm{CE}$ vs. $\mathrm{OH}$ exposure $\left(\mathrm{OH}_{\exp }\right)$ in the reactor for all reactor measurements and averages for $7 \%$ quantiles.

Figure S3: Measured vs. predicted ammonium assuming full neutralization ("Ammonium balance") for ambient and reactor data. Linear orthogonal distance regression fit lines, slope and $\mathrm{R}^{2}$ for each are also shown.

106

107

108

109

110
Figure S4: (a) Scatter plot of AMS mass vs. mass estimated from SMPS measurements for ambient and reactor data, with linear orthogonal distance regression fit slope and $\mathrm{R}^{2}$ for each. A one-to-one line and $+/-15 \%$ region is shown for reference. (b) Relative enhancement ratio from AMS and SMPS data with raw data, 20-minute averaged smooth data, linear orthogonal distance regression, line, fit slope and $\mathrm{R}^{2}$ for each.

Figure S5: Estimated particle transmission of inlet plumbing vs. particle diameter for reactor and ambient sampling lines for both AMS and SMPS measurements, calculated using the particle loss calculator of von der Weiden et al. (2009).

Figure S6: (a) Time series of SMPS mass measured below the AMS lens transmission size for ambient and reactor measurements. (b) Percent of estimated mass not measured by AMS, due to on particle losses in sampling lines and the AMS lens transmission at small sizes, for the reactor vs. total photochemical age in days (at $\mathrm{OH}=1.5 \times 10^{6}$ molec. $\mathrm{cm}^{-3}$ ), where all data is colored by $\triangle \mathrm{OA}$ mass with average $5 \%$ quantiles and standard error bars.

Figure S7: Modeled fate of low volatility organic gases (LVOCs) formed in the reactor vs. $\mathrm{OH}_{\exp }$ including wall loss, reaction with $\mathrm{OH}$, condensation on aerosol, and exiting the reactor, with a fit for the fraction condensing on aerosols in the reactor. 
Figure S8: AMS mass size distribution (vs. vacuum aerodynamic diameter, $d_{v a}$ ) for reactor and ambient OA, averaged from 20:00 on 2 June 2010 - 00:20 on 9 June 2010 for average nighttime ambient and reactor with no internal $\mathrm{OH}_{\exp }$ (dark reactor), and for $\sim 3.7$ days and $\sim 23.5$ days aging.

Figure S9: Times series of benzene, 1,3,5-trimethylbenzene, and toluene on top panel. Time series of ambient OOA, reactor OA mass enhancement, maximum reactor mass enhancement, and $\mathrm{O}_{\mathrm{x}}$ on bottom panel.

Figure S10: Ratio of organic aerosol to excess carbon monoxide (above background) vs. total photochemical age in days (at $\mathrm{OH}=1.5 \times 10^{6}$ molec. $\mathrm{cm}^{-3}$ ) for (a) the same data as Fig. 9, showing all data used to produce averages for quantiles of ambient and reactor vapor-loss corrected data. Also shown are the expected decays of benzene, toluene, and 1,3,5trimethylbenzene in the reactor vs. total photochemical age in days (at $\mathrm{OH}=1.5 \times 10^{6} \mathrm{molec} . \mathrm{cm}^{-}$ ${ }^{3}$ ), using reaction rates from Atkinson et al. (2006). (b) The same data as Fig. 9, showing reactor vapor loss-corrected data, but where excess $\mathrm{CO}$ is decreased by reaction with $\mathrm{OH}$ in the reactor, including means for $12 \%$ quantiles. Results from field studies in the northeastern US and Mexico City are shown for comparison to previous observations (DeCarlo et al., 2010). A fit to the data when $\mathrm{CO}$ is assumed to react with $\mathrm{OH}$ is shown.

Figure S11: The ratio of the gain of oxygen of OA observed in the reactor $(\Delta$ Oxygen in OA $=$ Oatoms, reactor $-\mathrm{O}_{\text {atoms, ambient }}$ ) to the total number of $\mathrm{OH}$ collisions with $\mathrm{OA}$ in the reactor vs. total photochemical age. The estimated number of $\mathrm{OH}$ collisions is calculated based on the methodology outlined in appendix A of DeCarlo et al. (2008).

Figure S12: Top panel: Mass fraction remaining (MFR) for OA vs. thermal denuder temperature for this CalNex-LA dataset, using the methods described in Huffman et al. (2008; 2009). Bottom panel: estimated volatility distribution of particle- and gas-phase species, calculated from the thermal denuder profile using the method of Faulhaber et al. (2009), on bottom panel.

\section{References}

Atkinson, R., Baulch, D. L., Cox, R. A., Crowley, J. N., Hampson, R. F., Hynes, R. G., Jenkin, M. E., Rossi, M. J., Troe, J., and Subcommittee, I.: Evaluated kinetic and photochemical data for atmospheric chemistry: Volume II: gas phase reactions of organic species, Atmos. Chem. Phys., 6, 3625-4055, 10.5194/acp-6-3625-2006, 2006.

Canagaratna, M. R., Jayne, J. T., Jimenez, J. L., Allan, J. D., Alfarra, M. R., Zhang, Q., Onasch, T. B., Drewnick, F., Coe, H., Middlebrook, A., Delia, A., Williams, L. R., Trimborn, A. M., Northway, M. J., DeCarlo, P. F., Kolb, C. E., Davidovits, P., and Worsnop, D. R.: Chemical and microphysical characterization of ambient aerosols with the aerodyne aerosol mass spectrometer, Mass Spectrom Rev, 26, 185-222, Doi 10.1002/Mas.20115, 2007.

DeCarlo, P. F., Dunlea, E. J., Kimmel, J. R., Aiken, A. C., Sueper, D., Crounse, J., Wennberg, P. O., Emmons, L., Shinozuka, Y., Clarke, A., Zhou, J., Tomlinson, J., Collins, D. R., Knapp, D., Weinheimer, A. J., Montzka, D. D., 
Campos, T., and Jimenez, J. L.: Fast airborne aerosol size and chemistry measurements above Mexico City and Central Mexico during the MILAGRO campaign, Atmos. Chem. Phys., 8, 4027-4048, 10.5194/acp-8-4027-2008, 2008.

DeCarlo, P. F., Ulbrich, I. M., Crounse, J., de Foy, B., Dunlea, E. J., Aiken, A. C., Knapp, D., Weinheimer, A. J., Campos, T., Wennberg, P. O., and Jimenez, J. L.: Investigation of the sources and processing of organic aerosol over the Central Mexican Plateau from aircraft measurements during MILAGRO, Atmos. Chem. Phys., 10, 5257-5280, 10.5194/acp-10-5257-2010, 2010.

Docherty, K. S., Aiken, A. C., Huffman, J. A., Ulbrich, I. M., DeCarlo, P. F., Sueper, D., Worsnop, D. R., Snyder, D. C., Peltier, R. E., Weber, R. J., Grover, B. D., Eatough, D. J., Williams, B. J., Goldstein, A. H., Ziemann, P. J., and Jimenez, J. L.: The 2005 Study of Organic Aerosols at Riverside (SOAR-1): instrumental intercomparisons and fine particle composition, Atmos. Chem. Phys., 11, 12387-12420, 10.5194/acp-11-12387-2011, 2011.

Faulhaber, A. E., Thomas, B. M., Jimenez, J. L., Jayne, J. T., Worsnop, D. R., and Ziemann, P. J.: Characterization of a thermodenuder-particle beam mass spectrometer system for the study of organic aerosol volatility and composition, Atmos. Meas. Tech., 2, 15-31, 10.5194/amt-2-15-2009, 2009.

Hayes, P. L., Ortega, A. M., Cubison, M. J., Froyd, K. D., Zhao, Y., Cliff, S. S., Hu, W. W., Toohey, D. W., Flynn, J. H., Lefer, B. L., Grossberg, N., Alvarez, S., Rappenglück, B., Taylor, J. W., Allan, J. D., Holloway, J. S., Gilman, J. B., Kuster, W. C., de Gouw, J. A., Massoli, P., Zhang, X., Liu, J., Weber, R. J., Corrigan, A. L., Russell, L. M., Isaacman, G., Worton, D. R., Kreisberg, N. M., Goldstein, A. H., Thalman, R., Waxman, E. M., Volkamer, R., Lin, Y. H., Surratt, J. D., Kleindienst, T. E., Offenberg, J. H., Dusanter, S., Griffith, S., Stevens, P. S., Brioude, J., Angevine, W. M., and Jimenez, J. L.: Organic aerosol composition and sources in Pasadena, California, during the 2010 CalNex campaign, Journal of Geophysical Research: Atmospheres, 118, 9233-9257, 10.1002/jgrd.50530, 2013.

Huffman, J. A., Ziemann, P. J., Jayne, J. T., Worsnop, D. R., and Jimenez, J. L.: Development and Characterization of a Fast-Stepping/Scanning Thermodenuder for Chemically-Resolved Aerosol Volatility Measurements, Aerosol Science and Technology, 42, 395-407, 10.1080/02786820802104981, 2008.

Huffman, J. A., Docherty, K. S., Aiken, A. C., Cubison, M. J., Ulbrich, I. M., DeCarlo, P. F., Sueper, D., Jayne, J. T., Worsnop, D. R., Ziemann, P. J., and Jimenez, J. L.: Chemically-resolved aerosol volatility measurements from two megacity field studies, Atmos. Chem. Phys., 9, 7161-7182, 10.5194/acp-9-7161-2009, 2009.

Jimenez, J. L., Jayne, J. T., Shi, Q., Kolb, C. E., Worsnop, D. R., Yourshaw, I., Seinfeld, J. H., Flagan, R. C., Zhang, X. F., Smith, K. A., Morris, J. W., and Davidovits, P.: Ambient aerosol sampling using the Aerodyne Aerosol Mass Spectrometer, J Geophys Res-Atmos, 108, 2003.

Knote, C., Brunner, D., Vogel, H., Allan, J., Asmi, A., Äijälä, M., Carbone, S., van der Gon, H. D., Jimenez, J. L., Kiendler-Scharr, A., Mohr, C., Poulain, L., Prévôt, A. S. H., Swietlicki, E., and Vogel, B.: Towards an online-coupled chemistry-climate model: evaluation of trace gases and aerosols in COSMO-ART, Geosci. Model Dev., 4, 1077-1102, 10.5194/gmd-4-1077-2011, 2011.

Lambe, A. T., Onasch, T. B., Massoli, P., Croasdale, D. R., Wright, J. P., Ahern, A. T., Williams, L. R., Worsnop, D. R., Brune, W. H., and Davidovits, P.: Laboratory studies of the chemical composition and cloud condensation nuclei (CCN) activity of secondary organic aerosol (SOA) and oxidized primary organic aerosol (OPOA), Atmos Chem Phys, 11, 8913-8928, DOI 10.5194/acp-11-8913-2011, 2011.

Middlebrook, A. M., Bahreini, R., Jimenez, J. L., and Canagaratna, M. R.: Evaluation of Composition-Dependent Collection Efficiencies for the Aerodyne Aerosol Mass Spectrometer using Field Data, Aerosol Sci Tech, 46, 258$271,2012$. 
Palm, B. B., Campuzano-Jost, P., Ortega, A. M., Day, D. A., Kaser, L., Jud, W., Karl, T., Hansel, A., Hunter, J. F., Cross, E. S., Kroll, J. H., Peng, Z., Brune, W. H., and Jimenez, J. L.: In situ secondary organic aerosol formation from ambient pine forest air using an oxidation flow reactor, Atmos. Chem. Phys., 16, 2943-2970, 10.5194/acp-16-29432016, 2016.

von der Weiden, S. L., Drewnick, F., and Borrmann, S.: Particle Loss Calculator - a new software tool for the assessment of the performance of aerosol inlet systems, Atmos. Meas. Tech. Discuss., 2, 1099-1141, 10.5194/amtd2-1099-2009, 2009.

Zhang, Q., Jimenez, J. L., Canagaratna, M. R., Allan, J. D., Coe, H., Ulbrich, I., Alfarra, M. R., Takami, A., Middlebrook, A. M., Sun, Y. L., Dzepina, K., Dunlea, E., Docherty, K., DeCarlo, P. F., Salcedo, D., Onasch, T., Jayne, J. T., Miyoshi, T., Shimono, A., Hatakeyama, S., Takegawa, N., Kondo, Y., Schneider, J., Drewnick, F., Borrmann, S., Weimer, S., Demerjian, K., Williams, P., Bower, K., Bahreini, R., Cottrell, L., Griffin, R. J., Rautiainen, J., Sun, J. Y., Zhang, Y. M., and Worsnop, D. R.: Ubiquity and dominance of oxygenated species in organic aerosols in anthropogenically-influenced Northern Hemisphere midlatitudes, Geophys. Res. Lett., 34, L13801, 10.1029/2007g1029979, 2007.

Zhang, X. F., Smith, K. A., Worsnop, D. R., Jimenez, J. L., Jayne, J. T., Kolb, C. E., Morris, J., and Davidovits, P.: Numerical characterization of particle beam collimation: Part II - Integrated aerodynamic-lens-nozzle system, Aerosol Science and Technology, 38, 619-638, 10.1080/02786820490479833, 2004. 


\section{Figure S1.}

(a)

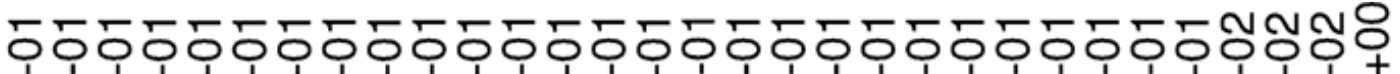

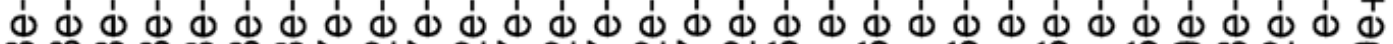
ก๊

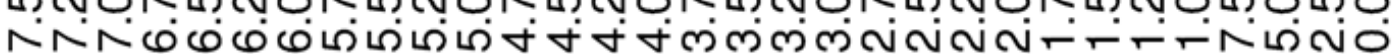

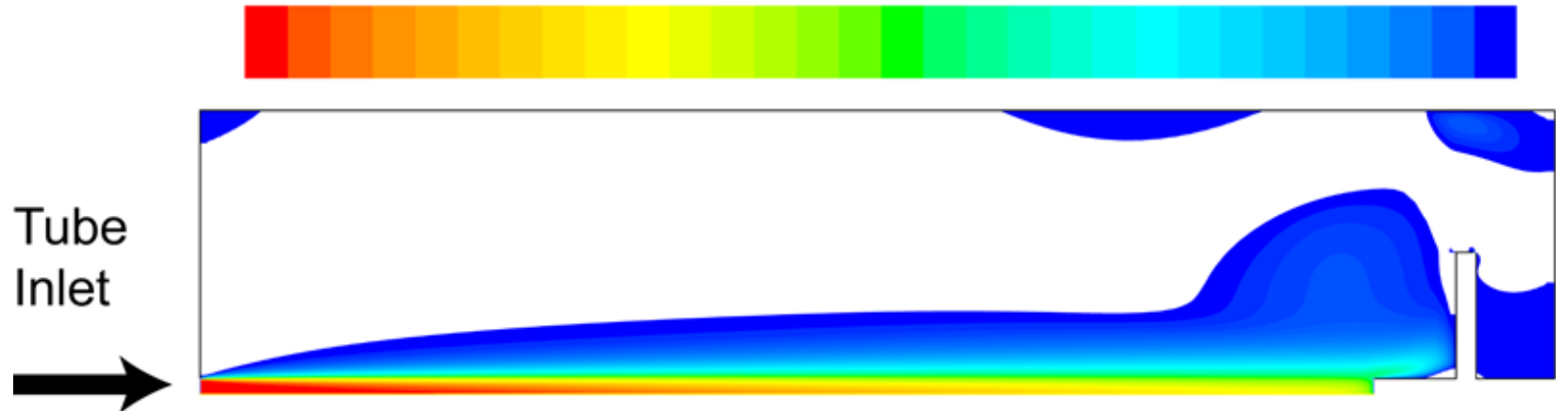

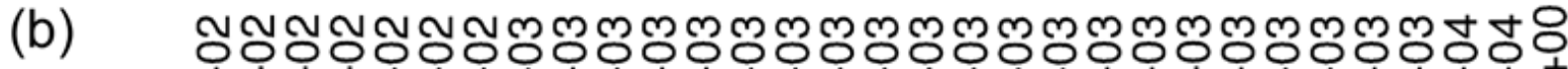

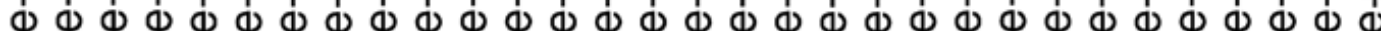
-

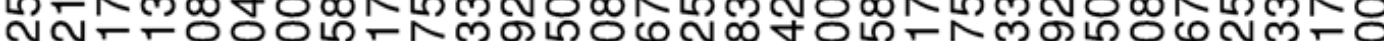
--.--

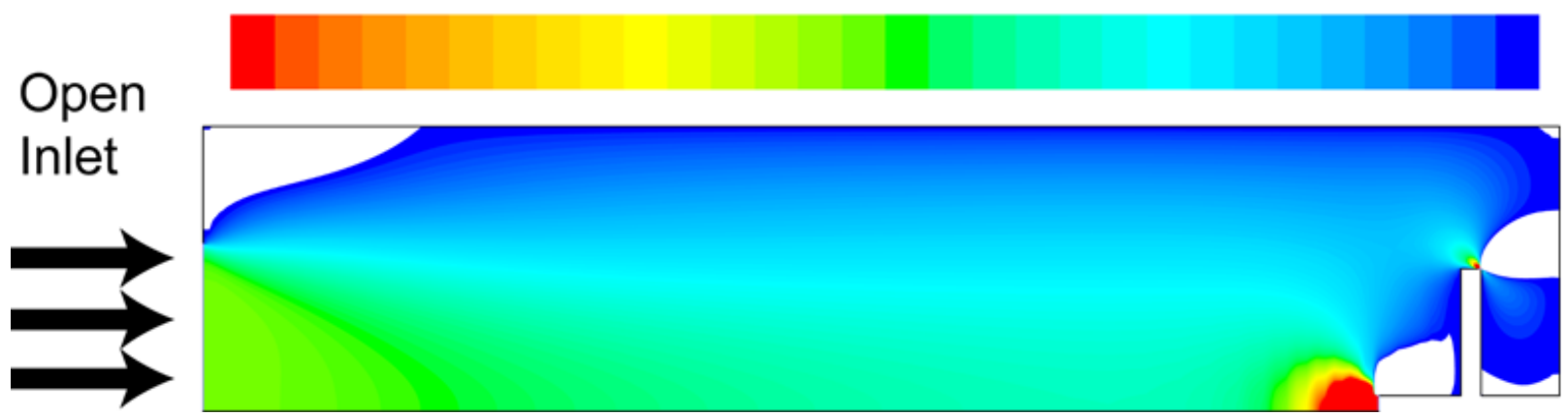




\section{Figure S2.}
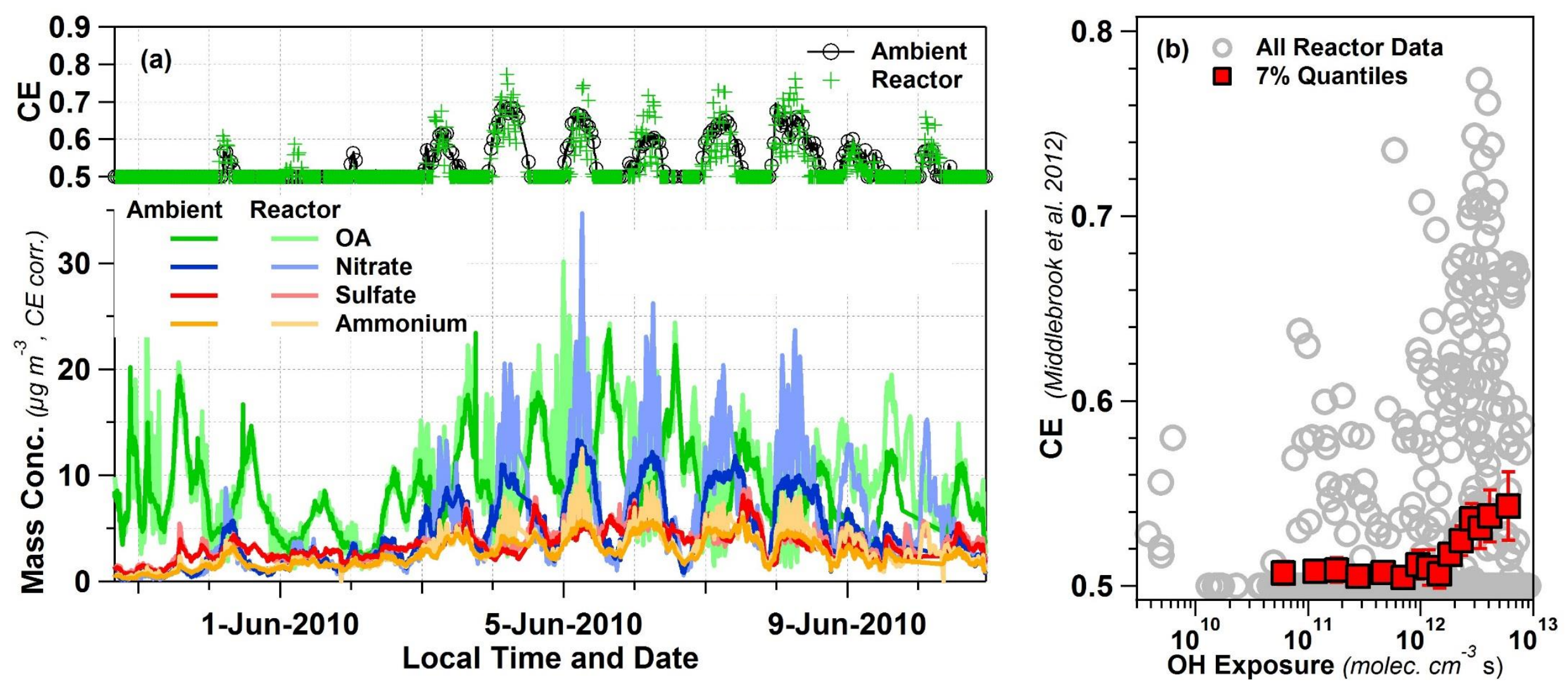


\section{Figure S3.}

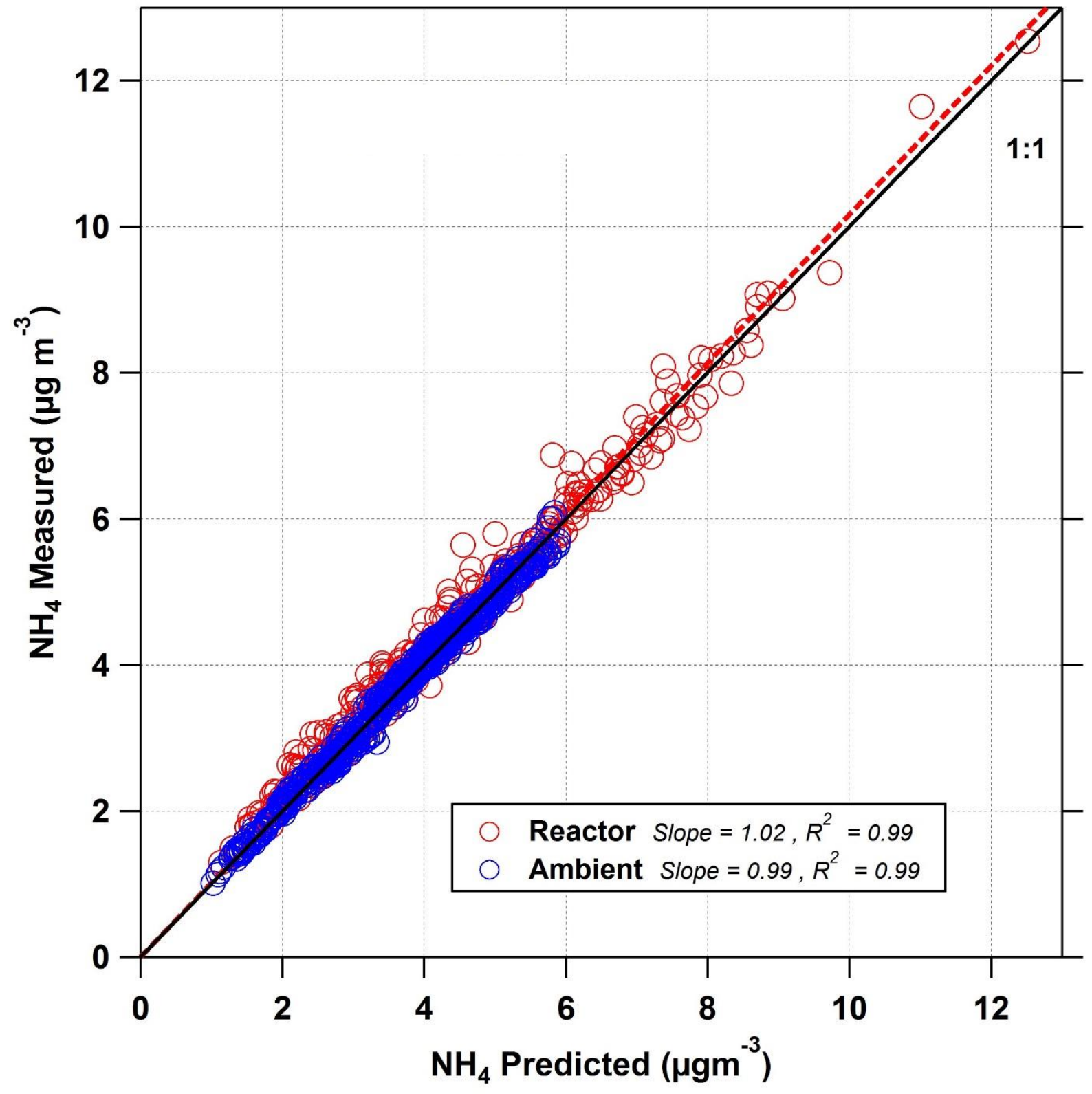




\section{Figure S4.}

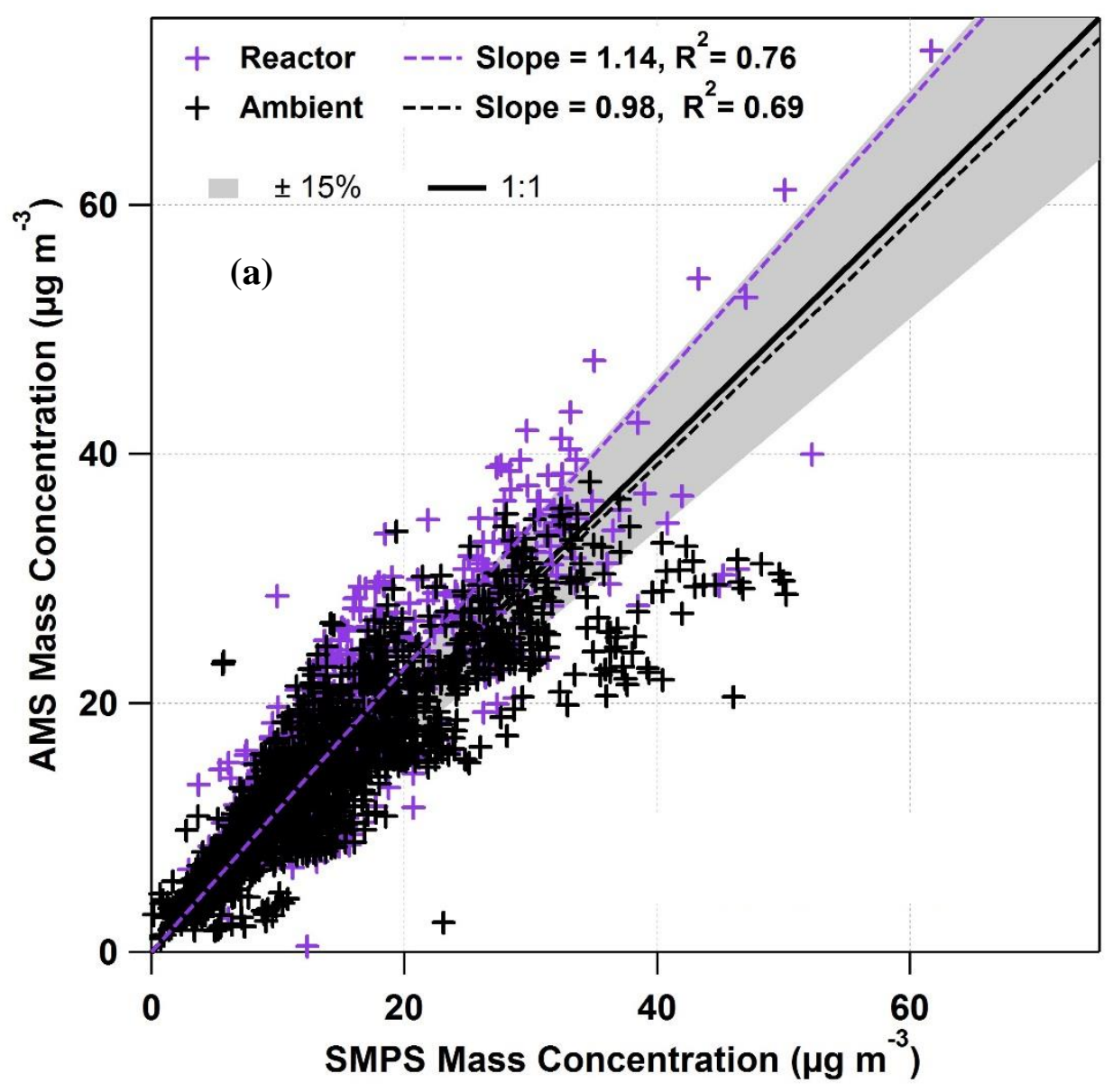

(b) 


\section{Figure S5.}

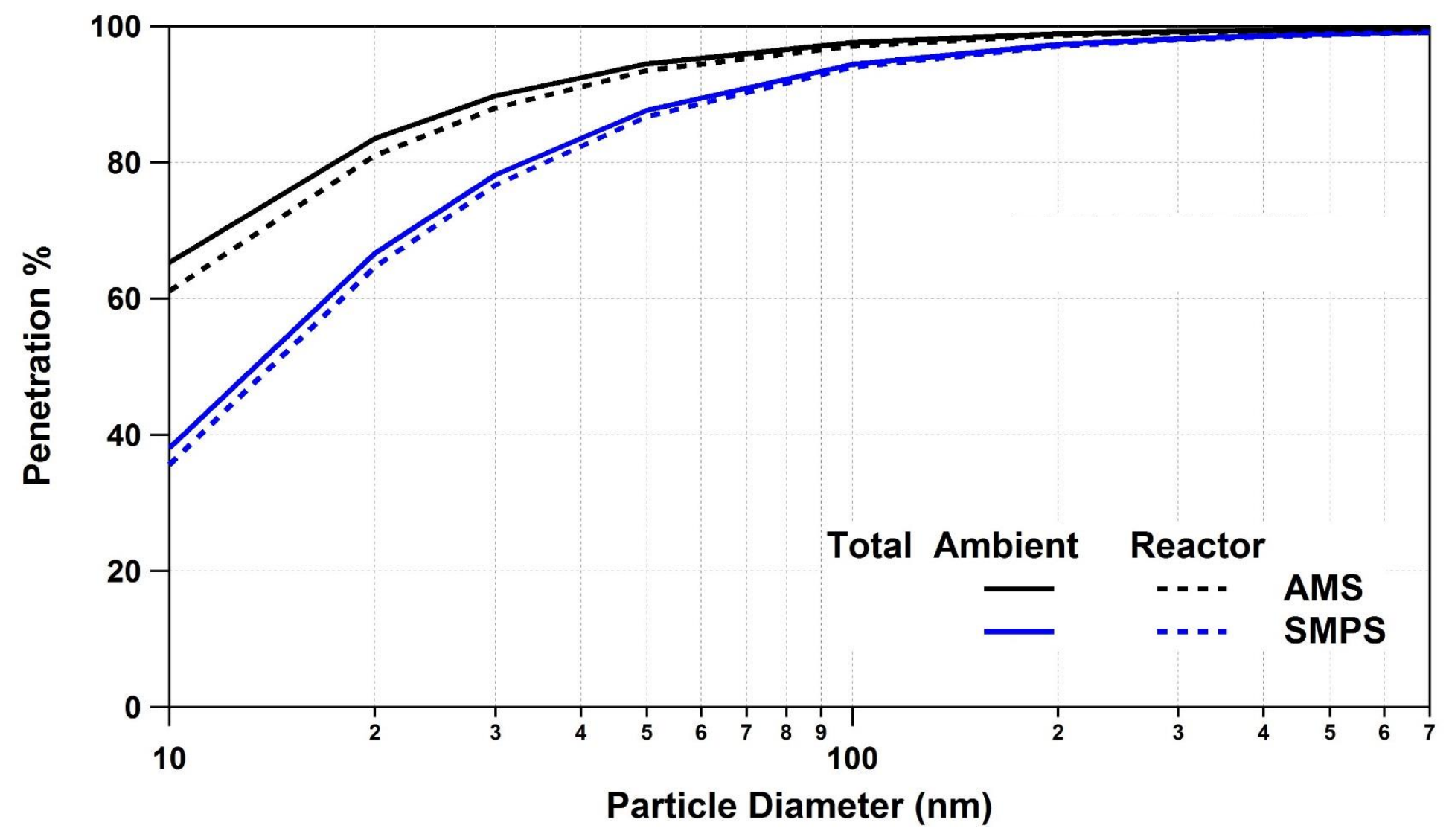


Figure S6.

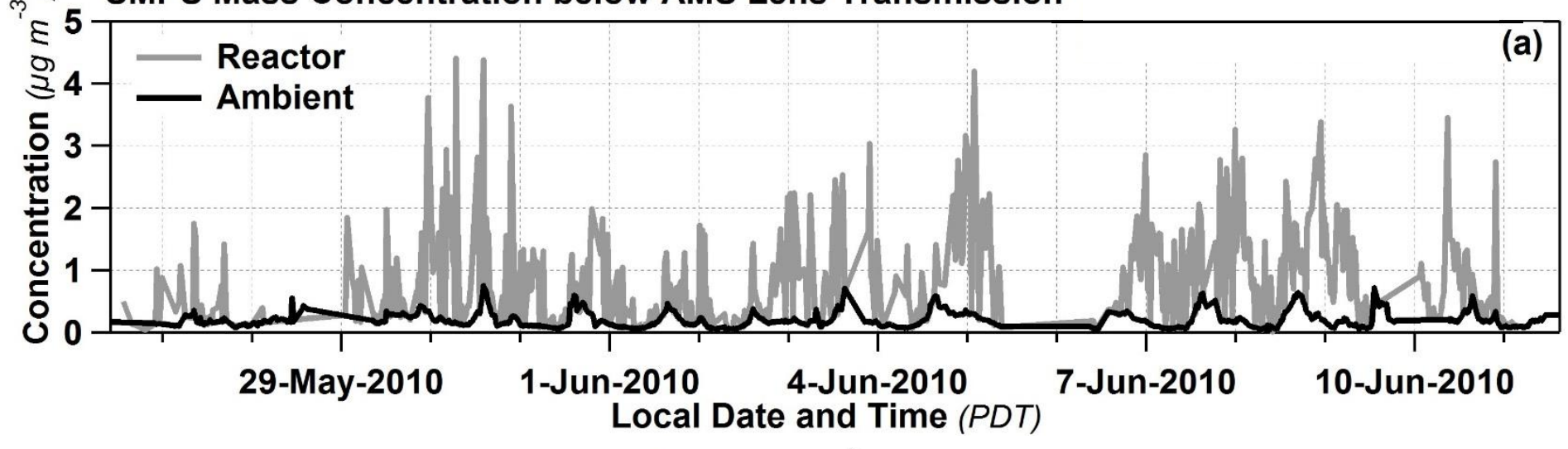
Local Date and Time (PDT)

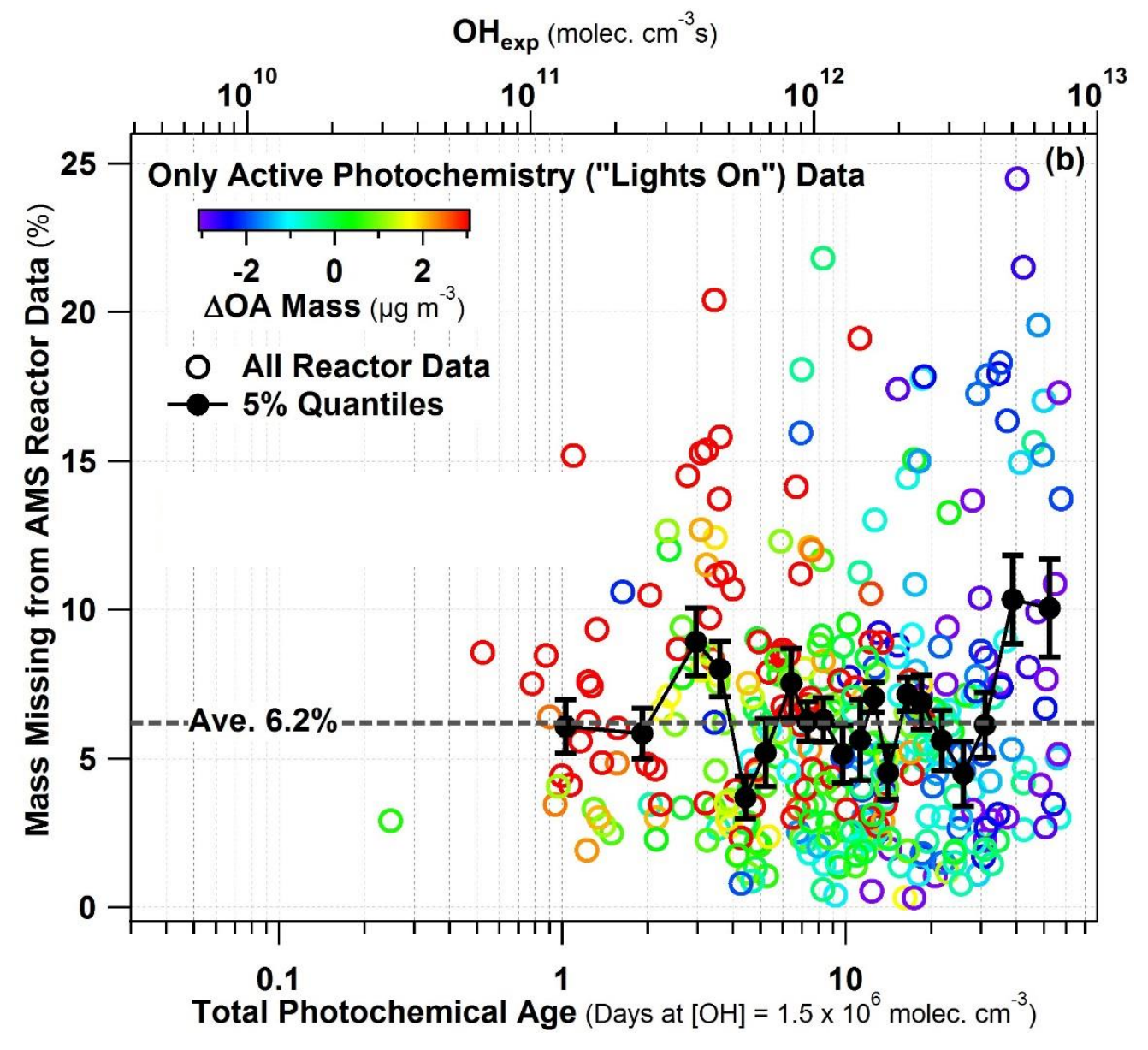


Figure S7.

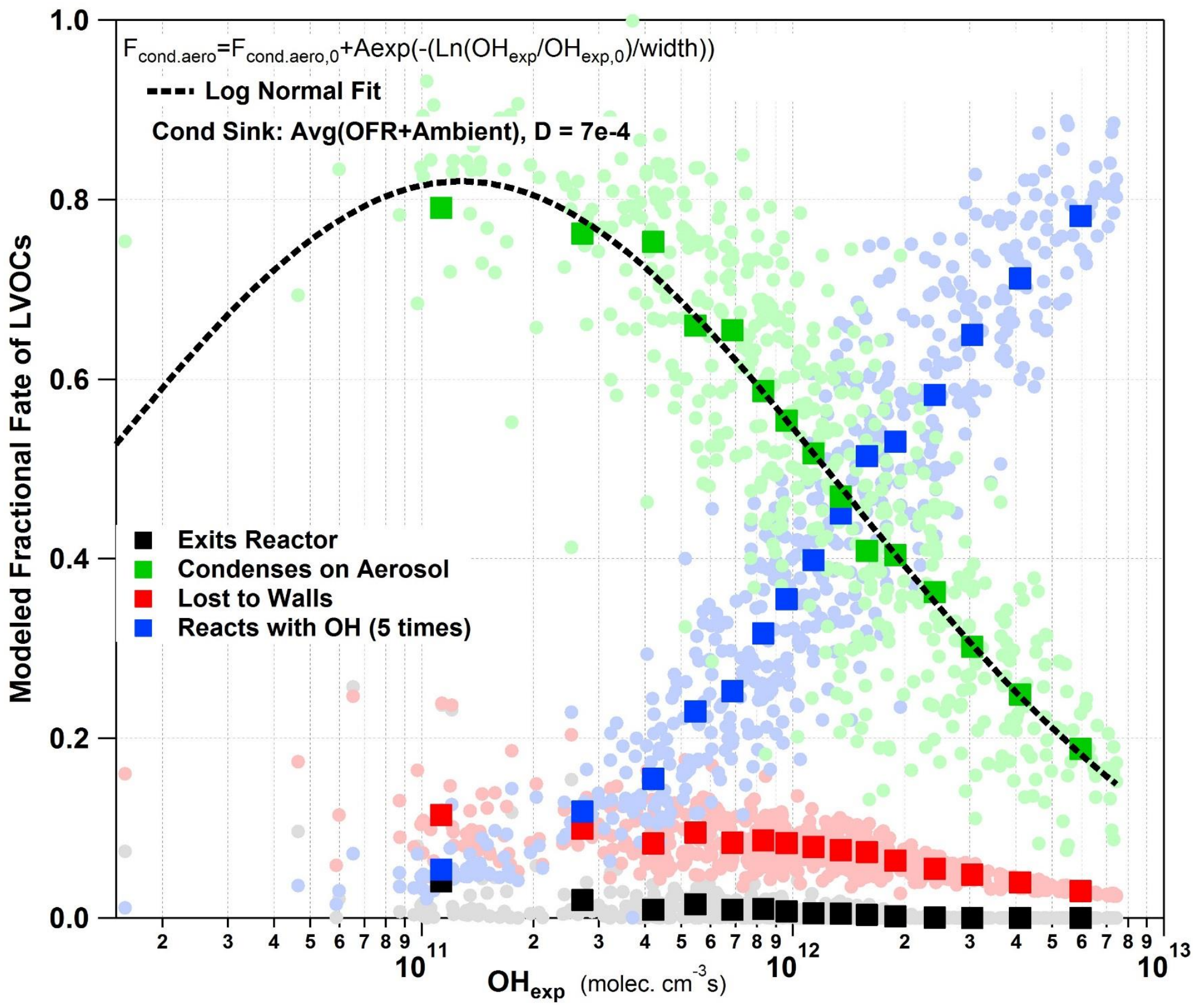


Figure S8.

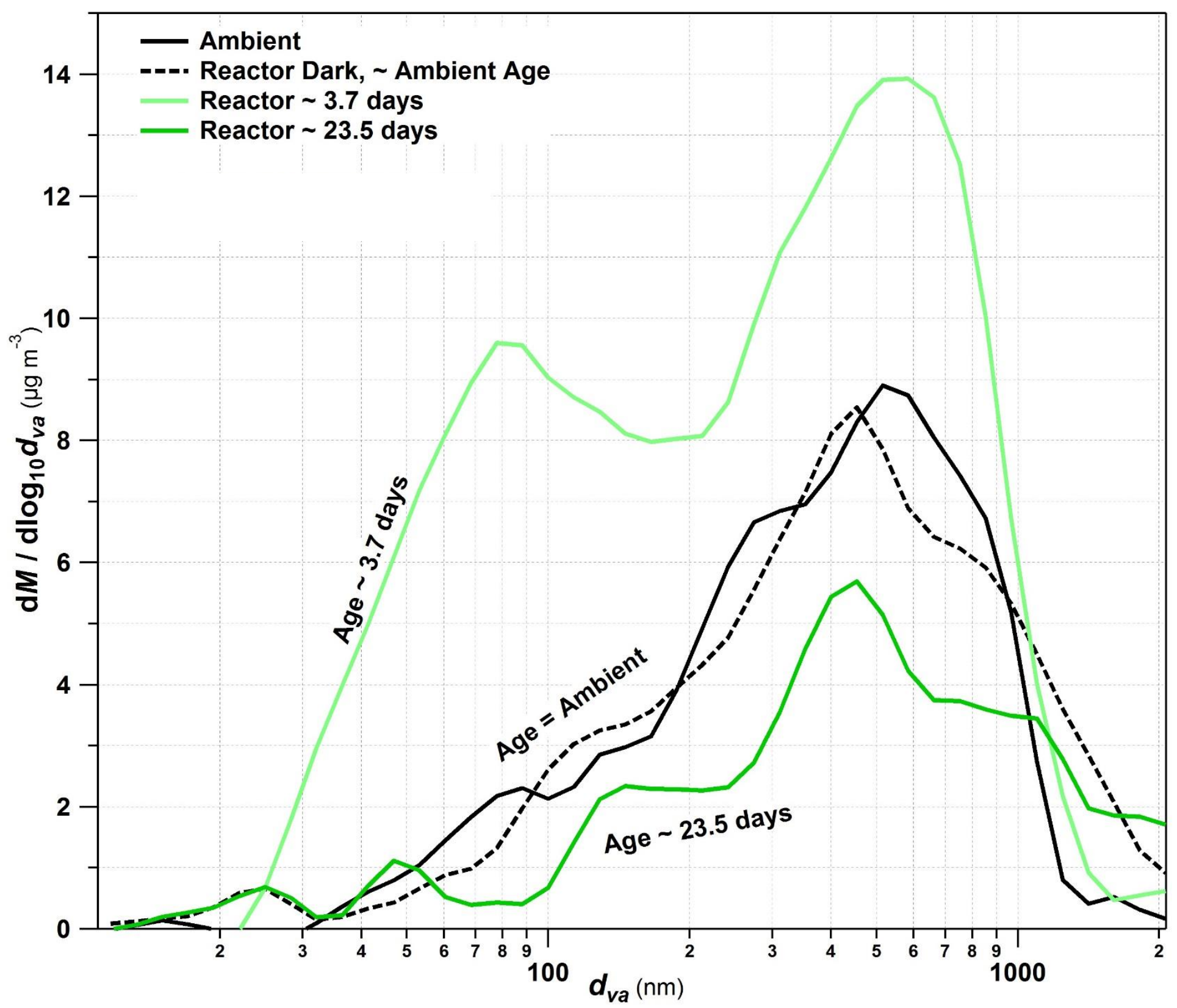


Figure S9.
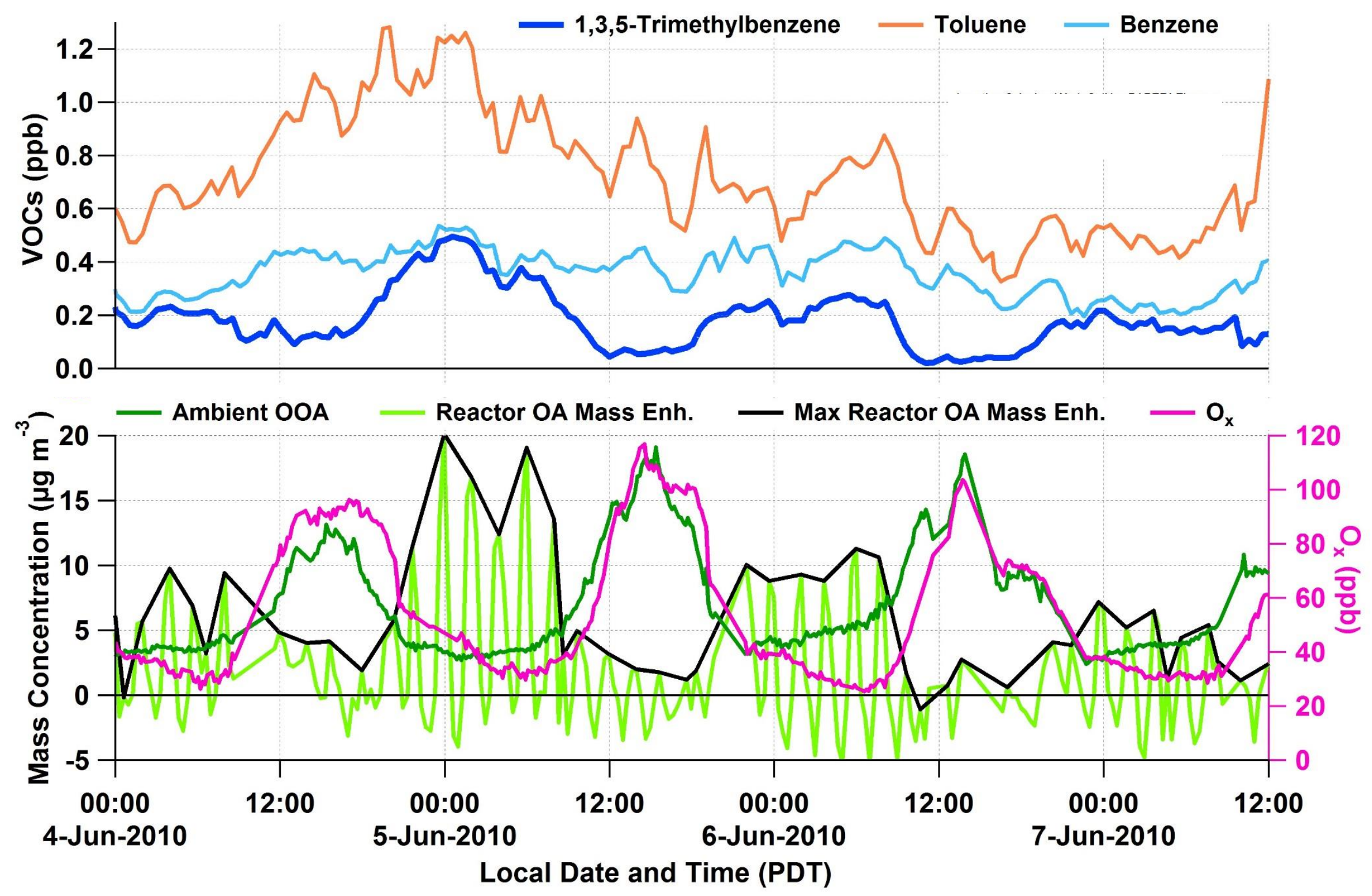


\section{Figure S11.}

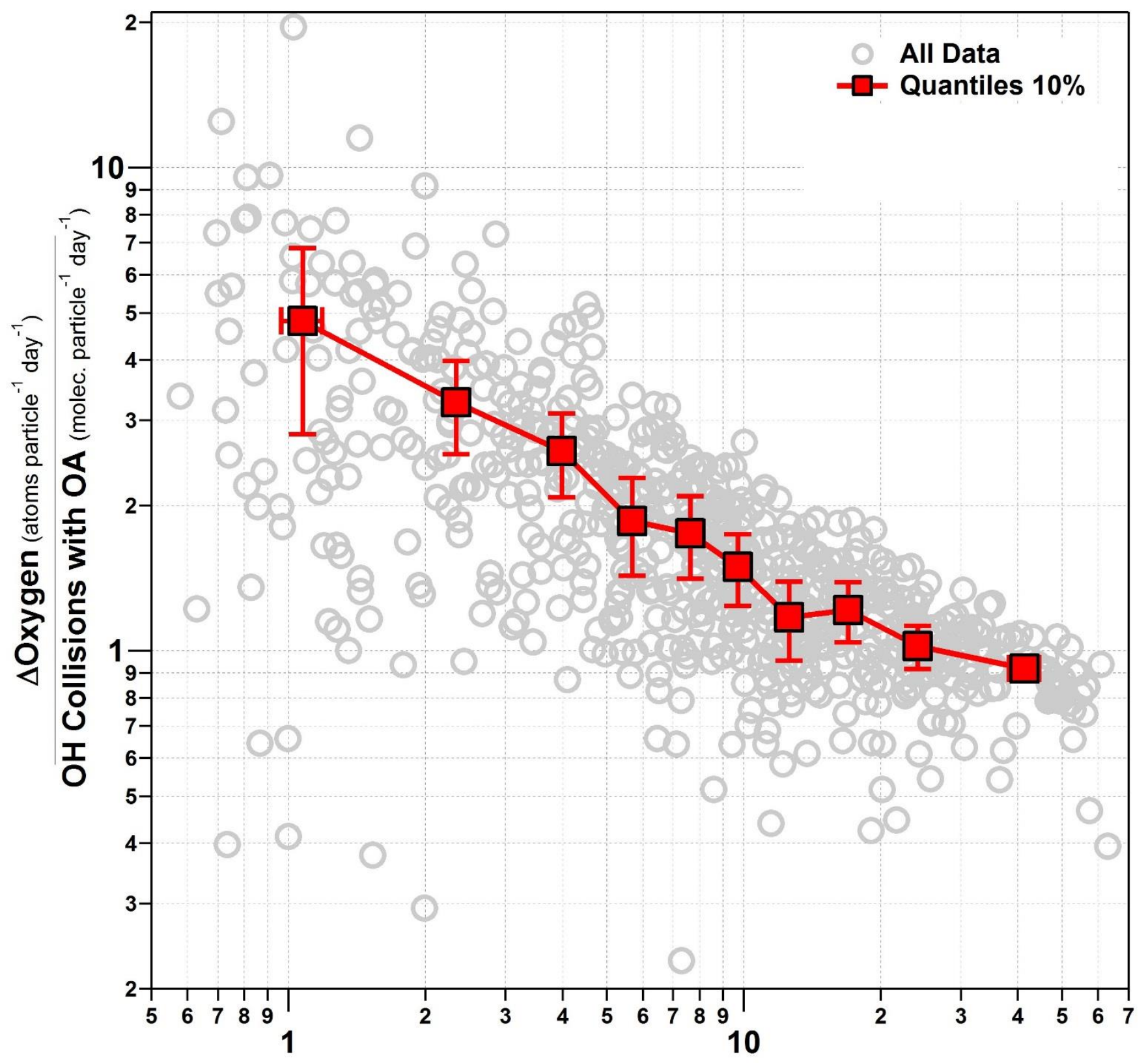

Total Photochemical Age (days) 


\section{Figure S12.}
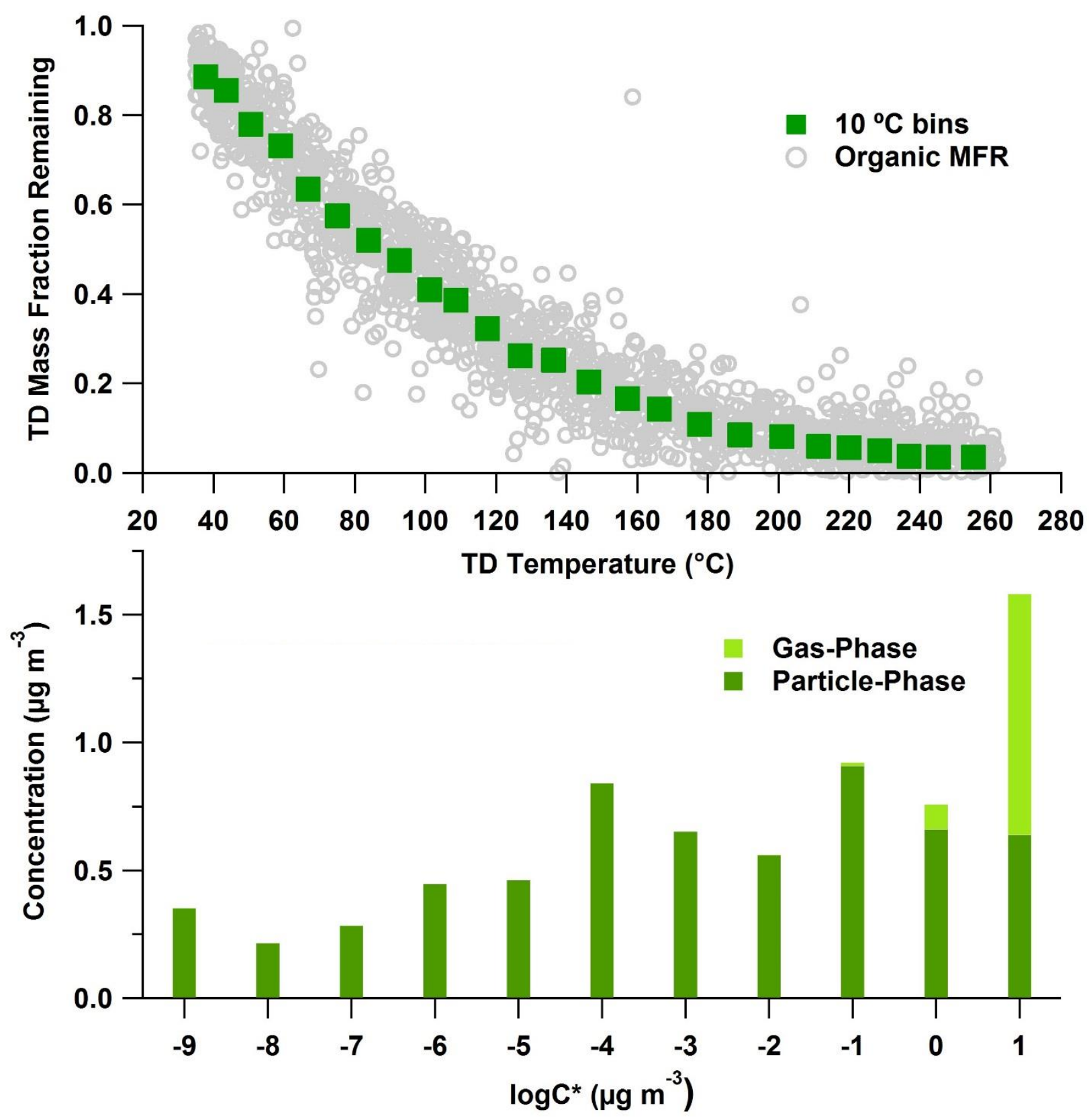